\title{
The Effectiveness of the KTP-el Service at the Population and Civil Registry Office of Parepare City
}

\author{
Iin Setyawati ${ }^{1}$, Muh. Nasrullah ${ }^{2}$, Rudi Salam ${ }^{3}$ \\ ${ }_{1,2,3}$ Universitas Negeri Makassar

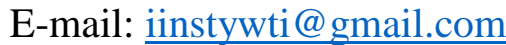

\begin{abstract}
Public services are implemented to provide satisfaction for service users whose implementation requires the principles of service. This study aims to determine the effectiveness of the KTP-el service at the Population and Civil Registry Office of Parepare City. This research uses a qualitative descriptive approach with 8 informants. Data collection uses observation, interview and documentation techniques. While the data analysis technique used consists of four ways, namely: data collection, data reduction, data presentation, and drawing conclusions. The results of this study indicate that the effectiveness of the KTP-el service at the Population and Civil Registry Office of Parepare City, is in the quite effective category. This is demonstrated through the focus of research that service procedures are in the effective category, employee discipline is in the effective category, fairness of service delivery is in the quite effective category, the reasonableness of cost is set effectively, service convenience is in the quite effective category.
\end{abstract}

Keywords: Effectiveness, service, KTP-el

\section{INTRODUCTION}

All public organizations must provide good, excellent and professional services to the community (Denhardt \& Denhardt, 2015; Niswaty, Juniati, Darwis, Salam, \& Arhas, 2019). One of the services which is the government's obligation is public service in the area of population and civil registration. Electronic ID Card (KTP-el) is one of the scopes of public services in the area of population. This card is needed by every citizen and must be owned as an ID to complete personal documents in carrying out daily life.

Providing public services easily, quickly and precisely will be categorized as effective (Andrews, 2014; Maryam, 2016; Neshkova \& Kostadinova, 2012). Effectiveness emphasizes the goals of an organization, if the organization succeeds in achieving its objectives, it can be said to have achieved effectiveness (Niswaty \& Darwis, 2015; Toding, Niswaty, \& Akib, 2015). Communities demand effective services, namely by using few/minimal resources to achieve maximum results. The community has the right to get services that must be provided by the government. Because basically the government is fully responsible for providing good services to the community (Akib, 2014). One of the services which is the government's obligation is public service in the area of population and civil registration. Electronic ID Card (KTP-el) is one of the scopes of public services in the area of population. This card is really needed by 


\section{0| Jurnal Office: Jurnal Pemikiran Ilmiah dan Pendidikan Administrasi Perkantoran Vol. 5, No. 2, July-December 2019, Hal 59-64}

every citizen and must be owned as identification to complete administrative needs (Wahyuni, Akib, \& Darwis, 2017).

The Parepare City Population and Civil Registry Office is an agency that has the responsibility and authority to carry out services in population administration affairs in the City of Parepare. This is because the Population and Civil Registry Office has complete population data and is the basis for making regional and national development policies and plans. However, in the implementation process there are still obstacles or problems that occur.

Based on preliminary observations made by researchers related to the effectiveness of the KTP-el Service at the Population and Civil Registry Office of Parepare City, the researchers found several facts in the form of the time period for printing Electronic ID Cards (KTP-el) which took a lot of time, inadequate facilities and infrastructure, the unavailability of KTP blanks, problematic server systems, and there are some employees who are less friendly in providing services to the public.

\section{METHOD}

This research uses descriptive qualitative research type. the aspect studied is "The Effectiveness of KTP-el Services" which aims to explain the Effectiveness of KTP-el Services to the Population and Civil Registry Office of Parepare City. The description of the focus of this research is service procedures, employee discipline, the fairness of service delivery, reasonable costs and convenience of service. The stages carried out in this research are problem identification, literature review, data collection, management and meaning of words and drawing conclusions. Data collection techniques and procedures, namely observation, interviews and documentation.

\section{RESULT AND DISCUSSION}

The results of the study were obtained based on interviews to describe the services of KTP-el at the Office of Population and Civil Registry using standard services. Service Standards are benchmarks that must be owned by public service providers and must be obeyed for service providers and recipients. The service standard in question, namely: service procedures, the discipline of service officers, justice in providing services, the fairness of service costs, and service convenience.

\section{Service Procedure}

Flowchart or mechanism for issuing KTP-el based on Decree of the Head of Population and Civil Registry No. 09b of 2018 concerning Application of Service Standards at the Population and Civil Registry Office of Parepare City, namely; First, residents or the community take a queue number. Then, head to the clerk when the queue number has been called. Then, the 
officer receives the file and verifies if the file is complete, will be continued, if the file is incomplete, returned to the community/residents to be completed first. Furthermore, for the community whose files have been completed, it will be directed by the dispatcher to record data for the applicant for issuing a new KTP-el. Then, employees who serve as ADB (Administrator Data Base) send and consolidate the KTP-el data to the Dukcapil Director-General database. After going through a series of recording processes, the officer will issue a new communityowned ID card. After the KTP-el is printed, the officer (Front Office) hands over the KTP-el to the community concerned. Procedure/flow of Electronic ID Card (KTP-el) services that refer to Presidential Regulation No. 96 of 2018 article 15 which is quite easy and very clear so that people feel more directed.

\section{Employee Discipline}

Discipline indicators can be measured from responsibility, obedience, accuracy, compliance, and attendance (absent). For government officials, discipline contains an element of loyalty, obedience and sacrifice in carrying out the tasks that have been given. That is, employees must sacrifice personal interests for the benefit of the community. Every Friday, all employees attend a briefing or performance evaluation, so that employees are able to maintain or improve their performance. If one of the staff is unable to attend, the Head of the Population Registration Service Department of Population and Civil Registry as the person in charge is waiting for information or confirmation to the person who is unable to attend one day before asking for permission, so that it can be temporarily replaced for the smooth service process. Regarding sanctions, first take a persuasive approach, giving advice to those concerned if it violates. If you have violated 3 (three) times, you will be given sanctions according to the level of violation. The discipline of officers in providing services is quite optimal because they are able to complete their work consistently and on time

\section{Justice Provides Services}

Justice in providing services is a demand that employees or government agencies acting as providers of public services treat or provide the rights and obligations of the community, be open-minded, tolerate and accept differences indiscriminately. Based on the results of the study, employees of the Office of Population and Civil Registry in providing Electronic ID Card (KTP-el) services to the community are still not completely fair because there are several persons who have one queue number, but organizing for two different people. This becomes homework for the government that acts as a public service provider to prioritize fair public services without discrimination. So, it will create excellent service especially at the Office of Population and Civil Registry. 


\section{$62 \mid$ Jurnal Office: Jurnal Pemikiran Ilmiah dan Pendidikan Administrasi Perkantoran Vol. 5, No. 2, July-December 2019, Hal 59-64}

\section{Reasonable Cost}

Determine the determination of the costs in services, a service provider must look at the conditions and types of services that will be provided to the community in a relevant manner. Providing information in a transparent and accountable way will make the people who get services not disadvantaged. In the electronic ID card service, there is no fee collection at all, because it has been regulated in Law Number 24 of 2013. As an implementing agency in the City / Regency, the Population and Civil Registry Service has the authority to provide services in Population Administration matters, all blank population documents, blank KTP-el, and other blanks are the obligations of the Ministry of the Interior.

\section{Service Comfort}

Convenience in providing services is one part of the service standards relating to work facilities, namely the availability of facilities and infrastructure that exist in a public service provider. In general, facilities and infrastructure support the success or failure of a government agency in providing public services. With the availability of neat, orderly and clean infrastructure facilities, the people being served will feel comfortable so that the work facilities used by service providers and facilities provided for service recipients can provide satisfaction to both parties. The condition of the room owned by the Office of Population and Civil Registry is still relatively small and still requires a larger room so that people are more comfortable waiting for the queue number. Therefore, the leaders and staff of Dinas Pendudukan dan Catatan Sipil Parepare are drafting a budget that will be submitted to the Parliament for the sake of creating good services.

\section{CONCLUSION}

Overall, the Electronic Resident Identity Card (KTP-el) service at the Population and Civil Registry Office of Parepare City when viewed from the indicators are quite effective. This can be seen from the focus of the research, namely the service procedures are in the effective category, employee discipline is in the effective category, the fairness of service delivery is in the category of quite effective, the reasonableness of costs is set effectively, the comfort of the service is in the category of quite effective.

\section{REFERENCES}

Akib, H. (2014). Implementasi Kebijakan Pelayanan Izin Mendirikan Bangunan (Studi pada Kantor Pelayanan Terpadu Kabupaten Gowa). Jurnal Ad'ministrare: Jurnal Pemikiran Ilmiah dan Pendidikan Administrasi Perkantoran, 1(1), 50-61.

Andrews, R. (2014). Performance management and public service improvement. The 
Public Policy Institute for Wales.

Denhardt, J. V., \& Denhardt, R. B. (2015). The New Public Service Revisited. Public Administration Review. https://doi.org/10.1111/puar.12347

Maryam, N. S. (2016). Mewujudkan good governance melalui pelayanan publik. Jurnal Ilmu Politik dan Komunikasi.

Neshkova, M. I., \& Kostadinova, T. (2012). The Effectiveness of Administrative Reform in New Democracies. Public Administration Review. https://doi.org/10.1111/j.1540-6210.2011.02483.x

Niswaty, R., \& Darwis, M. (2015). Efektivitas Pemanfaatan Komputer pada Kantor Camat Wotu Kabupaten Luwu Timur. Jurnal Office, 1(1), 8-12.

Niswaty, R., Juniati, F., Darwis, M., Salam, R., \& Arhas, S. H. (2019). The Effectiveness of Leadership Functions Implementation in The Makassar Departement of Manpower. JPBM (Jurnal Pendidikan Bisnis dan Manajemen), 5(1), 1-10.

Toding, A. R., Niswaty, R., \& Akib, H. (2015). Efektivitas Pelaksanaan Sistem Informasi Manajemen pada Kantor Wahana Lingkungan Hidup Sulawesi Selatan di Kota Makassar. Jurnal Office, 1(1), 71-79.

Wahyuni, N., Akib, H., \& Darwis, M. (2017). Keefektifan Pelayanan Kartu Tanda Penduduk Elektronik (KTP-EL). Jurnal Ilmiah Ilmu Administrasi Publik, 7(1), 110. 
64| Jurnal Office: Jurnal Pemikiran Ilmiah dan Pendidikan Administrasi Perkantoran Vol. 5, No. 2, July-December 2019, Hal 59-64 